\title{
Eosinophilic colitis in a boy with a novel XIAP mutation: a case report
}

\author{
Jiamei Tang ${ }^{1}$, Xiaoying Zhou', Lan Wang ${ }^{1}$, Guorui Hu', Bixia Zheng ${ }^{2}$, Chunli Wang ${ }^{2}$, Yan Lu', Yu Jin', \\ Hongmei Guo ${ }^{1}$ and Zhifeng Liu ${ }^{1 *}$
}

\begin{abstract}
Background: X-linked inhibitor of apoptosis (XIAP) deficiency is a rare primary immunodeficiency disease characterized by haemophagocytic lymphohistiocytosis, recurrent splenomegaly and inflammatory bowel disease (IBD). The only curative treatment is haematopoietic stem cell transplant (HSCT).

Case presentation: Here, we report the case of a 22-month-old male with a long history of abdominal distension and anaemia. Clinical and laboratory findings were consistent with eosinophilic colitis. To identify the underlying disease, we performed exome sequencing, which showed an unreported frameshift mutation in the XIAP gene.

Conclusion: We present eosinophilic colitis as the initial manifestation of XIAP deficiency for the first time in this article, which expands the mutation spectrum and phenotype of this disease.
\end{abstract}

Keywords: XIAP deficiency, Eosinophilic colitis, Gene detection

\section{Background}

X-linked inhibitor of apoptosis (XIAP) deficiency, also known as $\mathrm{X}$-linked lymphoproliferative syndrome type 2 (XLP-2), is a rare inherited disease caused by a gene mutation in XIAP, which is an important inhibitor of programmed cell death or apoptosis by blocking the activation of caspases 3, 7 and 9. The most commom characterization of XIAP deficiency is a key triad of clinical manifestations, including a high susceptibility to developing haemophagocytic lymphohistiocytosis (HLH) frequently triggered by Epstein-Barr virus (EBV) infection, recurrent splenomegaly and inflammatory bowel disease (IBD) with the features of Crohn's disease. To the best of our knowledge, the association of eosinophilic colitis with XIAP deficiency has not been reported in any literature to date. Here, we present the first case of XIAP deficiency complicated by eosinophilic colitis, expanding the clinical phenotype of XIAP deficiency.

\footnotetext{
* Correspondence: zfliu@njmu.edu.cn

'Department of Gastroenterology, Children's Hospital of Nanjing Medical University, No. 72 Guangzhou Road, Nanjing, Jiangsu Province 210008, China Full list of author information is available at the end of the article
}

\section{Case presentation}

A 22-month-old male was admitted to our Department of Gastroenterology because of a more than one-year history of abdominal distension with anaemia. His symptoms of abdominal distension was obvious after eating and improved slightly after defecation and flatulence. Meanwhile, the patient's stool appeared yellow and loose with visible food residue and was voided twice to four times a day.

In the past, the patient was once admitted to the local hospital with cervical lymphadenectasis and mild anaemia. At that time, he received oral iron treatment at home, but his abdominal distension showed no remission. The patient's first admission to our hospital was due to recurrent fever for over half a year in May 2018, and he was diagnosed as bronchopneumonia with pleural effusion and liver and cardiac damage according to the examination results. The patient was born through a full-term natural delivery and showed no abnormalities in the perinatal period. He had repetitive respiratory tract infections, and fever always occurred after vaccination. Perianal abscess resection was performed at 
the ages of 6 months and 8 months. His parents and sister were healthy.

Physical examination indicated that the patient's weight was $10 \mathrm{~kg}$ (z score: -1.55), and his height was 80 $\mathrm{cm}$ (z score: - 2.05). Hardened, enlarged lymph nodes were found on the neck and bilateral sides of the groins. Abdominal distention extended from the xiphoid to the bilateral sides of the groins where the vena epigastrica was exposed. The patient's abdominal circumference was $50.5 \mathrm{~cm}$. The soft liver and spleen extended $4 \mathrm{~cm}$ below the rib cage. We also found that he had two surgical scars because of a perianal abscess.

The abdominal CT suggested hepatosplenomegaly, a slightly thickened and strengthened intestinal wall of part of the abdomen (the left abdomen was more obvious), and multiple lymph nodes in the mesenteric, retroperitoneal and bilateral inguinal region (Fig. 6, in the Supplementary file). The patient's routine examination results are shown in Table 1 . His bone marrow aspiration revealed that the proliferation of granulocytes, erythroid cells and megakaryocytes was obviously active, and platelet clusters could be seen, ruling out haematological diseases. To determine the cause of abdominal distension, we performed endoscopy and two colonic biopsies were taken from different parts of the intestine, which identified mucous hyperaemia in the membrane with ulcers and erosions from the ileocaecum to the rectum (Fig. 1). The pathologic changes are shown in Fig. 2. However, the patient began to present fever with a temperature peak of $39.5^{\circ} \mathrm{C}$ on the third day after endoscopy; treatment with meropenem controlled this condition of fever, but his gastrointestinal symptoms did not improve. Considering that he may have immunodeficiency, we tried the empiric treatment of immunoglobulin replacement. To identify the underlying disease, exome sequencing was performed after obtaining written informed consent from the patient's parents. A novel frameshift mutation c.888-892delTAAAG (p. Asp296Aspfs*12) in exon 3 of the XIAP gene was identified (Fig. 3). This deletion results in a shift in the reading frame and formation of a premature stop codon at the $888-892$ position of the DNA strand, which corresponds to the 296-protein chain codon. As a result, peptide breakdown occurs earlier than the normal, which indicates the pathogenicity of this mutation. The patient's healthy mother and sister were heterozygous carriers (Fig. 4). For future monitoring, we recommend that the patient should conduct regular hospital follow-up, recheck the gastroenteroscopy regularly to observe the progression of gastrointestinal inflammation and injury, and histopathological examination will be conducted to keep abreast of the progress of the disease. However, his parents decided to pursue no further therapy (including HSCT) because of the expense, and the patient is currently experiencing recurrent infections again and undergoing follow-up at the outpatient clinic.

\section{Discussion and conclusions}

XIAP deficiency (OMIM 300635), also called X-linked lymphoproliferative syndrome type 2 (XLP-2), is a rare inherited disease caused by mutations in the XIAP gene, which encodes an important inhibitor of programmed cell death or apoptosis by blocking the activation of caspases 3, 7 and 9 and is related to signal transduction and activation processes, such as the NF- $\mathrm{kB}$, MAPK pathway,

Table 1 The patient's routine inspections results during hospitalization

\begin{tabular}{|c|c|c|}
\hline $\begin{array}{l}\text { Haematological values } \\
\text { (normal value) }\end{array}$ & $\begin{array}{l}\text { Feces Examination } \\
\text { (normal value) }\end{array}$ & $\begin{array}{l}\text { Immunological test } \\
\text { (normal value) }\end{array}$ \\
\hline $\begin{array}{l}\text { CRP:26 mg/L(0-10 mg/L) } \\
\mathrm{Hb}: 73 \mathrm{~g} / \mathrm{L}(110-160 \mathrm{~g} / \mathrm{L}) \\
\text { Eosinophil count:0.78 } \times 10 \wedge 9 / \mathrm{L}(0.05-0.5 \times 10 \wedge 9 / \mathrm{L})\end{array}$ & $\begin{array}{l}\text { Pyocyte: }+++/ H P \\
\text { RBC:1-3/HP }\end{array}$ & $\begin{array}{l}\operatorname{lgG} 10.6 \mathrm{~g} / \mathrm{L}(5.09-10.09 \mathrm{~g} / \mathrm{L}) \\
\operatorname{lgM} 0.677 \mathrm{~g} / \mathrm{L}(0.98-1.78 \mathrm{~g} / \mathrm{L}) \\
\lg 0.861 \mathrm{~g} / \mathrm{L}(0.31-0.67 \mathrm{~g} / \mathrm{L})\end{array}$ \\
\hline $\begin{array}{l}\text { PCT:1.69 ng/ml }(<0.05 \mathrm{ng} / \mathrm{mL}) \\
\text { Serum ferritin } 375.3 \mathrm{ng} / \mathrm{ml}(11-306.8 \mathrm{ng} / \mathrm{mL})\end{array}$ & $\begin{array}{l}\text { Fecal calprotectin: } 1295.5 \mu \mathrm{g} / \mathrm{g} \\
(<80 \mu \mathrm{g} / \mathrm{g})\end{array}$ & NK cells $4.05 \%$ (6-27\%) \\
\hline $\begin{array}{l}\text { Serum biochemistrytargets: } \\
\text { AST } 63 \mathrm{U} / \mathrm{L}(5-40 \mathrm{U} / \mathrm{L}) ; \\
\text { LDH } 449 \mathrm{U} / \mathrm{L}(80-285 \mathrm{U} / \mathrm{L}) ; \\
\text { TRIG } 1.91 \mathrm{mmol} / \mathrm{L}(0.56-1.69 \mathrm{mmol} / \mathrm{L}) ; \\
\text { HDL } 0.65 \mathrm{mmo} / \mathrm{L}(0.78-2.0 \mathrm{mmol} / \mathrm{L})\end{array}$ & $\begin{array}{l}\text { Clostridium difficile glutamic } \\
\text { dehydrogenase antigen: positive } \\
\text { Clostridium difficile toxin: negative }\end{array}$ & $\begin{array}{l}\text { Anti-nuclear antibody lgG: weakly positive; } \\
\text { IBD antibody: anti-intestinal goblet cell } \\
\text { antibody weakly positive; } \\
\text { Anti-neutrophil cytoplasmic antibody } \\
\text { perinuclear type: weakly positive }\end{array}$ \\
\hline $\begin{array}{l}\text { Four items of anemia screening: erythrocyte folic acid } 2120.2 \\
\text { nmol/L ( } 317-1894 \mathrm{nmol} / \mathrm{L}) ; \text { plasma erythropoietin } 27.89 \mathrm{IU} / \mathrm{L} \\
(2.59-18.5 \mathrm{IU} / \mathrm{L})\end{array}$ & Fecal bacterial culture:negative & \\
\hline $\begin{array}{l}\text { EBV-lgG:positive; EB-DNA: }<5.0 \mathrm{E}+2 \text { copies } / \mathrm{ml}(<5.0 \mathrm{E}+2 \\
\text { copies/ml) } \\
\text { CMV-DNA: }<5.0 \mathrm{E}+2 \text { copies } / \mathrm{ml}(<5.0 \mathrm{E}+2 \text { copies } / \mathrm{ml}) \\
\text { Parasite set:negative } \\
\text { Blood bacterial culture:negative }\end{array}$ & & \\
\hline
\end{tabular}

CRP C reactive protein; Hb Hemoglobin; PCT Procalcitonin; AST Aspartate transaminase;

LDH Lactatedehydrogenase; TRIG Triglyceride; HDL Highdensitylipoprotein; EBV Epstein-Barr virus; CMV Cytomegalovirus; RBC Red blood cell; IgG immunoglobin G; IgM Immunoglobin M; IgA Immunoglobin A; NK cells Natural killer cells; IBD Inflammatory bowel disease 

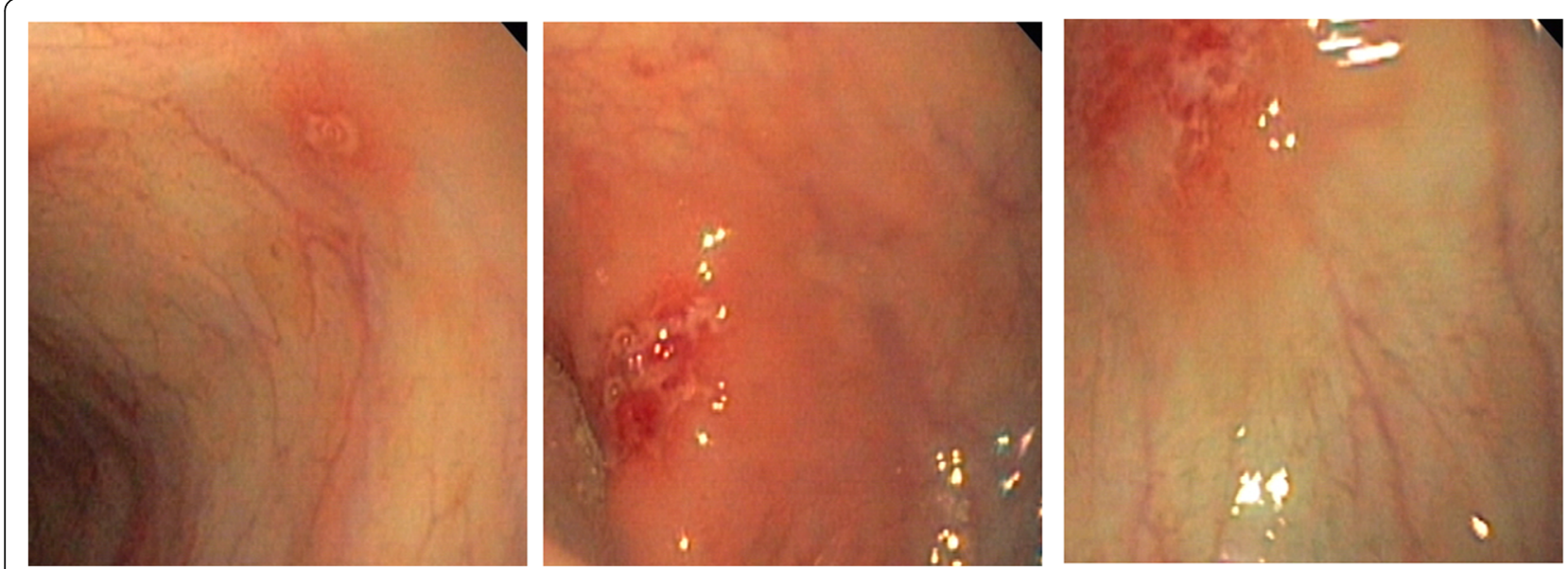

Fig. 1 Endonoscopy revealed scattered ulcers and erosions in the intestines of the patient with XIAP deficiency

NLRS, copper metabolism and autophagy [1]. Different patients may develop variable clinical phenotypes, including HLH, colitis or IBD, granulomatous lymphocytic interstitial lung disease (GLILD), granulomatous hepatitis, uveitis and juvenile idiopathic arthritis [2-4].

Based on our patient's examination results, we searched relevant case reports with the keyword "XIAP" in PubMed and summarized the clinical phenotypes of
XIAP deficiency. Thirty-two cases with complete clinical data were reported from 2010 to 2019 (Table 2). Most XIAP deficiency patients presented with HLH (45.45\%), followed by IBD (33.33\%), and fewer with uveitis (6.06\%), juvenile idiopathic arthritis (3.03\%), GLILD and granulomatous hepatitis (3.03\%), hypogammaglobulinemia (3.03\%), Langerhans cell histiocytosis (LCH) (3.03\%) and asymptomatic (3.03\%). However, different studies

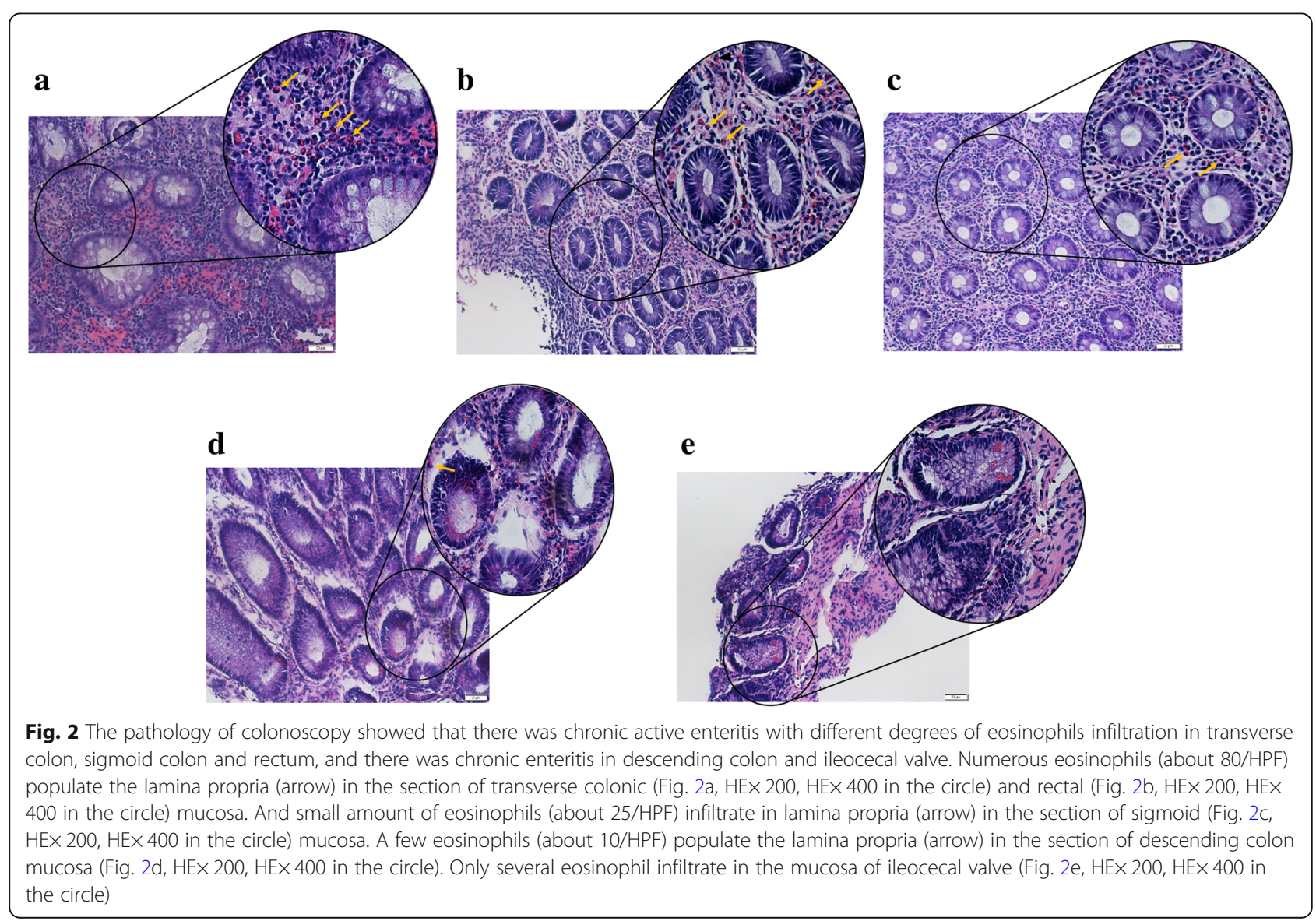




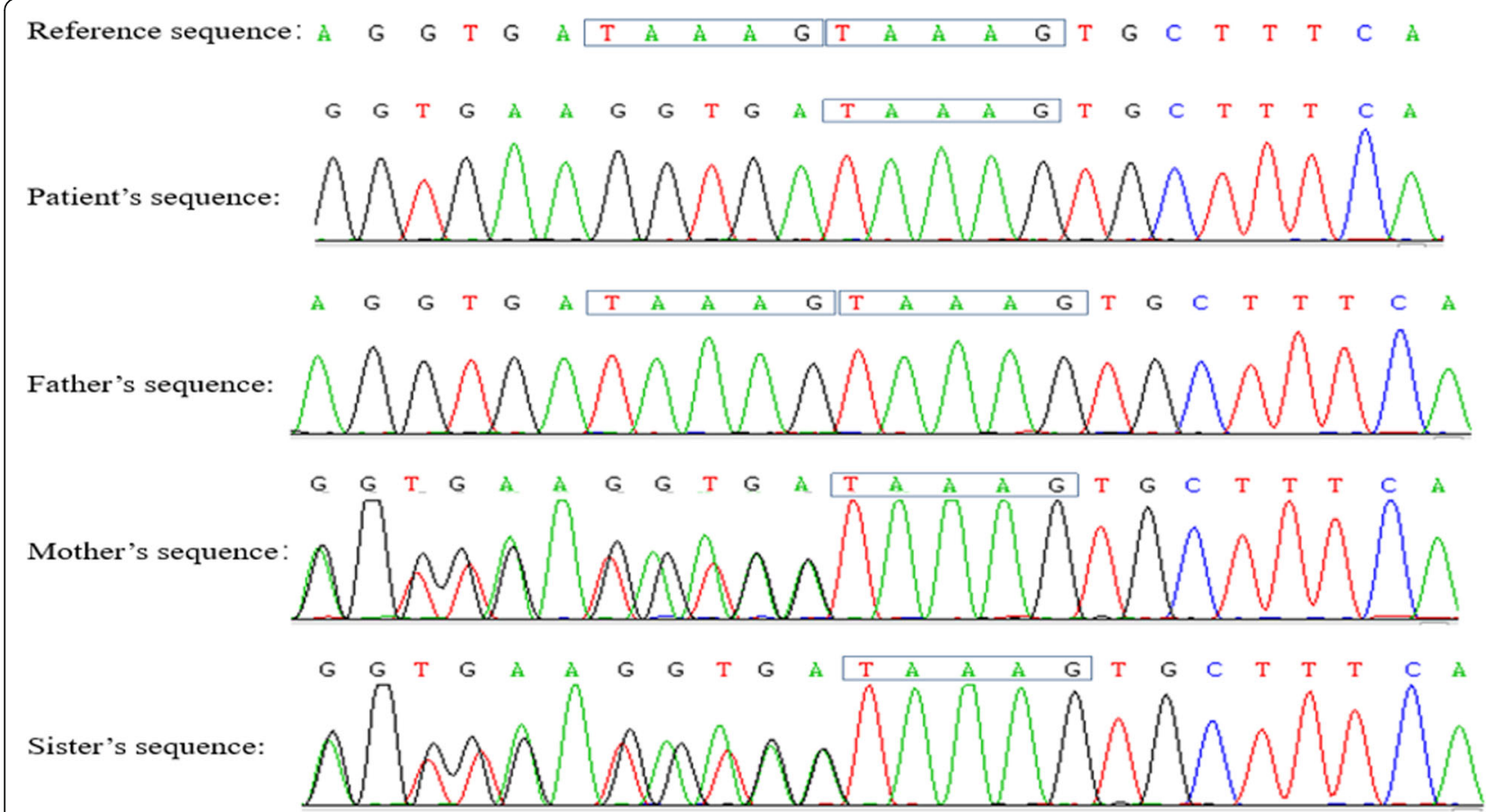

Fig. 3 Genetic test results of their familiy showed that the XIAP gene sequence of the father was normal, but the patient, his sister and mother had frame-shift mutation:c.888(exon3)-c.892(exon3) del TAAAG chrX:123022479-123,022,483. p.Asp296Aspfs*12(NM:001167.3, Reference genome: Hg19)

may be different in this respect. For example, a review found that $16 \%$ of XIAP patients showed hypogammaglobulinemia in five countries, including France, England, Germany, USA and Japan as of 2014 [1]. Our literature review showed that about $3 \%$ of patients showed hypogammaglobulinemia from 2010 to 2019. This is a significant discrepancy, which results from the difference of the included case samples and ages covered by the document retrieval. We found that the complication of eosinophilic colitis in patients with XIAP deficiency, which is characterized by abdominal distension, was not reported so far. Some patients can exhibit different complications, such as LCH complicated with HLH

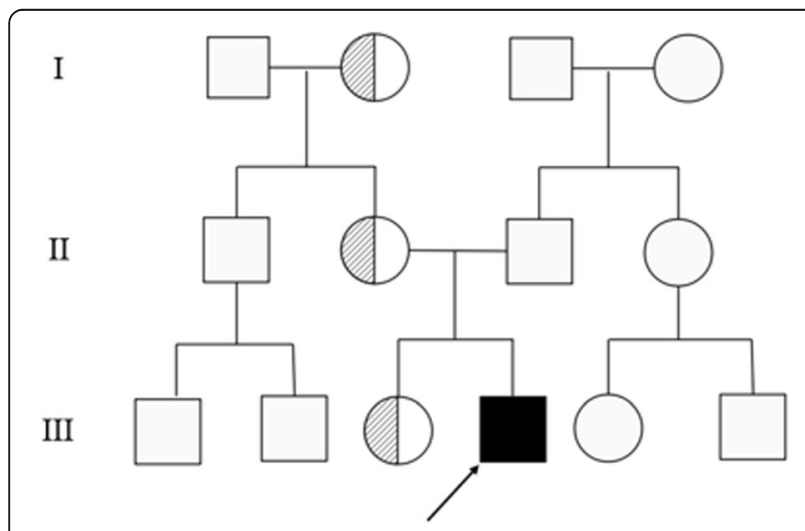

Fig. 4 The patient's family tree and Crohn's disease complicated with anterior uveitis [5, 26]. Patients with XIAP deficiency may have a variety of coincident symptoms of complications, and most (including our patient) exhibit recurrent fevers and refractory infections. Positive signs of hepatosplenomegaly occur in all patients, including our patient, and anaemia, liver function and coagulation abnormalities ensue. Our patient also showed abdominal distension from the age of 1 month, which to our understanding was caused by poor intestinal digestive function related to colitis. This finding suggests that children who have abdominal symptoms as the first manifestation and are prone to repeated infections with partial clinical manifestations of HLH (but not in accordance with the criteria for HLH2004) should cause clinicians to be alert to XIAP deficiency complicated with eosinophilic colitis, and early gene detection should be carried out. More than one hundred mutations in the XIAP gene have been reported in the Human Gene Mutation Database (HGMD). The frameshift mutation p. Asp296Aspfs*12 of our patient was not previously described in any literature or database. This is the first reported case of eosinophilic colitis occurring with a background of XIAP deficiency. Our empirical treatments, such as high-grade antibiotics and immunoglobulin replacement, temporarily relieve symptoms in children but did not cure the present patient. Unfortunately, the optimal treatment for this child is unknown, and there remains no established standard of 
Table $\mathbf{2}$ Literature retrieval: clinical phenotypes frequency of XIAP deficiency

\begin{tabular}{|c|c|c|c|}
\hline Disease phenotype & $\begin{array}{l}\text { Case } \\
\text { number (\%) }\end{array}$ & $\begin{array}{l}\text { Mean age } \\
\text { of } \\
\text { onset } \\
\text { (months) }\end{array}$ & Clinical feature \\
\hline $\mathrm{IBD}[5-14]$ & $\begin{array}{l}n= \\
11(33.33)\end{array}$ & 46.27 & $\begin{array}{l}\text { Prolonged fever, abdominal pain、 diarrhea with or without blood and mucus, growth } \\
\text { failure、 perianal desease、anemia、recurrent infection、 hepatosplenomegaly }\end{array}$ \\
\hline HLH [15-24] & $\begin{array}{l}n= \\
15(45.45)\end{array}$ & 28.79 & Persistent fever, pancytopenia、 EBV infection、 hepatosplenomegaly, lymphadenopathy \\
\hline $\begin{array}{l}\text { GLILD and granulomatous } \\
\text { hepatitis [2] }\end{array}$ & $n=1(3.03)$ & 240 & Progressive cough、dyspnea \\
\hline Uveitis $[3,5]$ & $n=2(6.06)$ & 144 & Decreased visual acuity, arthralgias, abdominal pain、weight loss、 sinus infection \\
\hline $\begin{array}{l}\text { Juvenile idiopathic arthritis } \\
\text { [4] }\end{array}$ & $n=1(3.03)$ & 60 & Prolonged fever, pancytopenia, generalized macular rash, periodic abdominal pains \\
\hline $\begin{array}{l}\text { Hypogammaglobulinemia } \\
\text { [25] }\end{array}$ & $n=1(3.03)$ & $\mathrm{N}$ & Hypoimmunity \\
\hline $\begin{array}{l}\text { Langerhans cell } \\
\text { histiocytosis [26] }\end{array}$ & $n=1(3.03)$ & 13 & Recurrent ear discharge、fever、 hemorrhagic papules、 hepatosplenomegaly \\
\hline Asymptomatic [25] & $n=1(3.03)$ & $\mathrm{N}$ & No clinical manifestation \\
\hline
\end{tabular}

IBD Inflammatory Bowel Disease, HLH Hemophagocytic lymphohistiocytosis, GLILD granulomatous lymphocytic interstitial lung disease, EBV Epstein-Barr virus, N: not mentioned

care for management. The only curative treatment for XIAP deficiency is HSCT.

Eosinophilic colitis is a type of eosinophilic gastrointestinal characterized by pathologic eosinophilic infiltration of the colon leading to organ dysfunction and clinical symptoms including (but not limited to) nausea, vomiting, diarrhoea, abdominal pain, abdominal distention, weight loss, and isolated ascites. IBD is part of the differential diagnosis of eosinophilic colitis in clinical work due to overlapping symptoms. Further association between XIAP deficiency and IBD has been established through epidemiologic studies, as about $4 \%$ of male patients with early onset IBD have been found to have a mutation in XIAP and the majority of XIAP variants are associated with a selective defect in NOD1/2 signalling, impaired NOD1/2-mediated activation of NF- $\mathrm{B}$, and altered NF-kB-dependent cytokine production [27]. Therefore, we hypothesized that an abnormality of the NOD2 signalling pathway may be related to the occurrence of XIAP deficiency with eosinophilic colitis. Genome-wide transcript profiles have revealed that levels of TH2 cytokines (e.g., IL4, IL5, and IL13) and the eosinophil-related chemokine eotaxin-3 (CCL26) are upregulated in eosinophilic gastrointestinal tissue [28]. Therefore, we speculate that the Th2-type immune response, which is a downstream pathway of NOD2, can be involved in eosinophilic colitis. Based on these speculative theories, some experimental data need to be supplemented, and more clinical cases and experiments are needed.

In summary, we report for the first time a boy of Chinese origin with a novel XIAP mutation who presented the feature of eosinophilic colitis. Our findings extend the phenotypic spectrum of XIAP deficiency. From this case review, we speculated that early detection of clinical symptoms is challenging in patients with XIAP deficiency, contributing to diversity of and difficulty in distinguishing among clinical symptoms. Therefore, we should be alert to XIAP deficiency with eosinophilia in view of repeated immunosuppression combined with long-term and intractable abdominal symptoms.

\section{Supplementary information}

Supplementary information accompanies this paper at https://doi.org/10. 1186/s12887-020-02075-Z.

Additional file 1. Fig. 5 Esophagogastroduodenoscopy showed no abnormality in esophagus, stomach and duodenum. (A: esophagus; B: preventriculus; C: fundus of stomach; D: Gastric body; E: gastric angle; F: gastric antrum; G: duodenal bulb; $\mathrm{H}$ : descending part of duodenum).

Additional file 2. Fig. 6 The abnormal CT findings of the patient. A: The axial image of contrast-enhanced computed tomography scan shows hepatosplenomegaly (asterisk) and intestinal wall thickening (arrow);B: Axial unenhanced computed tomography shows slightly enlarged mesenteric lymph nodes (arrow); C:The axial image of computed tomography scan shows intestinal wall thickening suspicious (arrow); D:Computed tomography with intravenous contrast comfirms the thickened intestinal wall (arrow).

\section{Abbreviations}

XIAP: X-linked inhibitor of apoptosis; XLP-2: X-linked lymphoproliferative syndrome type 2; HSCT: Haematopoietic stem cell transplant;

HLH: Haemophagocytic lymphohistiocytosis; EBV: Epstein-barr virus; IBD: Inflammatory bowel disease; GLILD: Granulomatous lymphocytic interstitial lung disease; LCH: Langerhans cell histiocytosis; HGMD: The human gene mutation database

Acknowledgements

The authors wish to thank this XIAP deficiency patient and his family. 


\section{Consent for publication}

Written informed consent was obtained from the patient's parents for publication of this case report, and the proof of consent can be requested at any time.

\section{Authors' contributions}

JMT researched the topic, reviewed the research, and wrote, edited, and submitted the case report. XYZ and LW assisted with finding some of the research studies. GRH, CLW, BXZ and YL critically reviewed the manuscript. YJ and HMG helped analysed the case and guided the writing. ZFL provided guidance and oversight to JMT and critically reviewed the manuscript. All authors read and approved the final manuscript.

\section{Funding}

This work was supported by the National Natural Science Foundation of China (grant number: 81570470). The funders had no role in study design, data collection and analysis, decision to publish, or preparation of the manuscript.

\section{Availability of data and materials}

Data sharing is not applicable to this article, as no datasets were generated or analysed during the current study.

\section{Ethics approval and consent to participate}

Our article was published with the consent of the child's parents and approved by the Ethics Committee of Children's Hospital of Nanjing Medical University.

\section{Competing interests}

The authors declare that they have no competing interests.

\section{Author details}

'Department of Gastroenterology, Children's Hospital of Nanjing Medical University, No. 72 Guangzhou Road, Nanjing, Jiangsu Province 210008, China. ${ }^{2}$ Nanjing Key Laboratory of pediatrics, Children's Hospital of Nanjing Medical University, No. 72 Guangzhou Road, Nanjing, Jiangsu Province 210008, China.

\section{Received: 26 August 2019 Accepted: 6 April 2020}

Published online: 18 April 2020

\section{References}

1. Aguilar C, Latour S. X-linked inhibitor of apoptosis protein deficiency: more than an X-linked lymphoproliferative syndrome [J]. J Clin Immunol. 2015; 35(4):331-8. https://doi.org/10.1007/s10875-015-0141-9.

2. Steele $\mathrm{CL}$, Dore $M$, Ammann $S$, Loughrey M, Montero A, Burns SO, Morris EC, Gaspar B, Gilmour K, Bibi S, Shendi H, Devlin L, Speckmann C, Edgar DM. $\mathrm{X}$-linked inhibitor of apoptosis complicated by granulomatous lymphocytic interstitial lung disease (GLILD) and granulomatous hepatitis [J]. J Clin Immunol. 2016;36(7):733-8. https://doi.org/10.1007/s10875-016-0320-3.

3. Basiaga ML, Weiss PF, Behrens EM. BIRC4 mutation: an important rare cause of uveitis [J]. J Clin Rheumatol. 2015;21(8):444-7. https://doi.org/10.1097/rhu. 0000000000000327.

4. Shabani M, Razaghian A, Alimadadi H, Shiari R, Shahrooei M, Parvaneh N. Different phenotypes of the same XIAP mutation in a family: a case of XIAP deficiency with juvenile idiopathic arthritis [J]. Pediatr Blood Cancer. 2019; 66(5):e27593. https://doi.org/10.1002/pbc.27593.

5. Coelho R, Peixoto A, Amil-Dias J, Trindade E, Campos M, Magina S, CharbitHenrion F, Lenoir C, Latour S, Magro F, Macedo G. Refractory monogenic Crohn's disease due to X-linked inhibitor of apoptosis deficiency [J]. Int J Colorectal Dis. 2016;31(6):1235-6. https://doi.org/10.1007/s00384-015-2442-0.

6. Quaranta M, Wilson R, Goncalves Serra E, Pandey S, Schwerd T, Gilmour K, Klenerman P, Powrie F, Keshav S, Travis SPL, Anderson CA, Uhlig HH. Consequences of Identifying XIAP deficiency in an adult patient with inflammatory bowel disease [J]. Gastroenterology. 2018;155(1):231-4. https:// doi.org/10.1053/j.gastro.2018.03.069.

7. Girardelli M, Arrigo S, Barabino A, Loganes C, Morreale G, Crovella S, Tommasini A, Bianco AM. The diagnostic challenge of very early-onset enterocolitis in an infant with XIAP deficiency [J]. BMC Pediatr. 2015;15:208. https://doi.org/10.1186/s12887-015-0522-5.

8. Sunseri WM, Kugathasan S, Keljo DJ, Greer JB, Ranganathan S, Cross RK, Siegel CA. Regueiro M D. IBD LIVE case series--case 3: very early-onset inflammatory bowel disease: when genetic testing proves beneficial [J]. Inflamm Bowel Dis. 2015;21(12):2958-68. https://doi.org/10.1097/mib. 0000000000000650.

9. Kelsen JR, Dawany N, Martinez A, Grochowski CM, Maurer K, Rappaport E, Piccoli DA, Baldassano RN, Mamula P, Sullivan KE, Devoto M. A de novo whole gene deletion of XIAP detected by exome sequencing analysis in very early onset inflammatory bowel disease: a case report [J]. BMC Gastroenterol. 2015;15:160. https://doi.org/10.1186/s12876-015-0394-z.

10. Dziadzio M, Ammann S, Canning C, Boyle F, Hassan A, Cale C, Elawad M, Fiil BK, Gyrd-Hansen M, Salzer U, Speckmann C, Grimbacher B. Symptomatic males and female carriers in a large Caucasian kindred with XIAP deficiency [J]. J Clin Immunol. 2015;35(5):439-44. https://doi.org/10.1007/s10875-0150166-0.

11. Tsuma Y, Imamura T, Ichise E, Sakamoto K, Ouchi K, Osone S, Ishida H, Wada T, Hosoi H. Successful treatment of idiopathic colitis related to XIAP deficiency with allo-HSCT using reduced-intensity conditioning [J]. Pediatr Transplant. 2015;19(1):E25-8. https://doi.org/10.1111/petr.12405.

12. Beser OF, Conde CD, Kutlu T, Cullu Cokugras F, Boztug K, Erkan T. Inflammatory bowel disease with lethal disease course caused by a nonsense mutation in BIRC4 encoding X-linked inhibitor of apoptosis protein (XIAP)[J]. J Pediatr Gastroenterol Nutr. 2016;62(5):e41-3. https://doi. org/10.1097/mpg.0000000000000504.

13. Lekbua A, Ouahed J, O'Connell AE, Kahn SA, Goldsmith JD, Imamura T, Duncan CN, Kelsen JR, Worthey E, Snapper SB, Softic S. Risk-factors associated with poor outcomes in VEO-IBD secondary to XIAP deficiency: a case report and literature review [J]. J Pediatr Gastroenterol Nutr. 2019. https://doi.org/10.1097/mpg.0000000000002297.

14. Xu LJ, Luo YY, Yu JD, Lou JG, Fang YH, Chen J. X-linked inhibitor of apoptosis deficiency manifested as Crohn's disease: a case report and literature review [J]. Zhonghua Er Ke Za Zhi. 2018;56(1):43-7. https://doi.org/ 10.3760/cma.j.issn.0578-1310.2018.01.011.

15. Jin YY, Zhou W, Tian ZQ, Chen TX. Variable clinical phenotypes of X-linked lymphoproliferative syndrome in China: Report of five cases with three novel mutations and review of the literature [J]. Hum Immunol. 2016;77(8): 658-66. https://doi.org/10.1016/j.humimm.2016.06.005.

16. Chellapandian D, Krueger J, Schechter T, Gassas A, Weitzman S, Naqvi A, Ali M. Successful allogeneic hematopoietic stem cell transplantation in XIAP deficiency using reduced-intensity conditioning [J]. Pediatr Blood Cancer. 2016;63(2):355-7. https://doi.org/10.1002/pbc.25756.

17. Holle JR, Marsh RA, Holdcroft AM, Davies SM, Wang L, Zhang K, Jordan MB. Hemophagocytic lymphohistiocytosis in a female patient due to a heterozygous XIAP mutation and skewed X chromosome inactivation [J]. Pediatr Blood Cancer. 2015;62(7):1288-90. https://doi.org/10.1002/pbc.25483.

18. Yang $X$, Hoshino A, Taga T, Kunitsu T, Ikeda Y, Yasumi T, Yoshida K, Wada T, Miyake K, Kubota T, Okuno Y, Muramatsu H, Adachi Y, Miyano S, Ogawa S, Kojima S, Kanegane H. A female patient with incomplete hemophagocytic lymphohistiocytosis caused by a heterozygous XIAP mutation associated with non-random X-chromosome inactivation skewed towards the wildtype XIAP allele [J]. J Clin Immunol. 2015;35(3):244-8. https://doi.org/10. 1007/s10875-015-0144-6.

19. Varghese AS, Lee H, Bonney D, Hughes S, Wynn R. Complications of reduced Intensity conditioning HSCT for XIAP deficiency (alloimmune cytopenias and HLH) successfully managed with donor lymphocyte infusion [J]. J Pediatr Hematol Oncol. 2015;37(3):e198-9. https://doi.org/10.1097/mph. 0000000000000191.

20. Vieth S, Ammann S, Schwarz K, Hartel C, Schultz C, Lehmberg K, Lauten M. Clinical phenotype and functional analysis of a rare XIAP/BIRC4 mutation [J]. Klin Padiatr. 2013;225(6):343-6. https://doi.org/10.1055/s-0033-1355393.

21. Worth AJ, Nikolajeva O, Chiesa R, Rao K, Veys P, Amrolia PJ. Successful stem cell transplant with antibody-based conditioning for XIAP deficiency with refractory hemophagocytic lymphohistiocytosis [J]. Blood. 2013;121(24): 4966-8. https://doi.org/10.1182/blood-2013-01-478735.

22. Gulez N, Aksu G, Berdeli A, Karaca N, Tanriverdi S, Kutukculer N, Azarsiz E. Xlinked lymphoproliferative syndrome and common variable immunodeficiency may not be differentiated by SH2D1A and XIAP/BIRC4 genes sequence analysis [J]. Case Rep Med. 2011;2011:121258. https://doi. org/10.1155/2011/121258.

23. Zhao M, Kanegane H, Ouchi K, Imamura T, Latour S, Miyawaki T. A novel XIAP mutation in a Japanese boy with recurrent pancytopenia and splenomegaly [J]. Haematologica. 2010;95(4):688-9. https://doi.org/10.3324/ haematol.2009.018010 
24. O'Rafferty C, Velangi M, Lawson S, Hiwarkar P, Motwani J. IFN block, treosulfan conditioning and alphabeta T cell deplete PBSCT for XIAPdeficient HLH [J]. J Clin Immunol. 2017;37(6):511-3. https://doi.org/10.1007/ s10875-017-0413-7.

25. Yang X, Kanegane H, Nishida N, Imamura T, Hamamoto K, Miyashita R, Imai K, Nonoyama S, Sanayama K, Yamaide A, Kato F, Nagai K, Ishii E, van Zelm MC, Latour S, Zhao XD, Miyawaki T. Clinical and genetic characteristics of XIAP deficiency in Japan [J]. J Clin Immunol. 2012;32(3):411-20. https://doi. org/10.1007/s10875-011-9638-z.

26. Guo X, Li Q, Gao J. Langerhans cell histiocytosis complicated with hemophagocytic lymphohistiocytosis in a boy with a novel XIAP mutation: a case report [J]. Medicine (Baltimore). 2018;97(44):e13019. https://doi.org/ 10.1097/md.0000000000013019.

27. Zeissig Y, Petersen BS, Milutinovic S, Bosse E, Mayr G, Peuker K, Hartwig J, Keller A, Kohl M, Laass MW, Billmann-Born S, Brandau H, Feller AC, Rocken C, Schrappe M, Rosenstiel P, Reed JC, Schreiber S, Franke A, Zeissig S. XIAP variants in male Crohn's disease [J]. Gut. 2015;64(1):66-76. https://doi.org/10. 1136/gutjnl-2013-306520

28. Caldwell JM, Collins MH, Stucke EM, Putnam PE, Franciosi JP, Kushner JP, Abonia JP, Rothenberg ME. Histologic eosinophilic gastritis is a systemic disorder associated with blood and extragastric eosinophilia, TH2 immunity, and a unique gastric transcriptome [J]. J Allergy Clin Immunol. 2014;134(5): 1114-24. https://doi.org/10.1016/j.jaci.2014.07.026.

\section{Publisher's Note}

Springer Nature remains neutral with regard to jurisdictional claims in published maps and institutional affiliations.

Ready to submit your research? Choose BMC and benefit from:

- fast, convenient online submission

- thorough peer review by experienced researchers in your field

- rapid publication on acceptance

- support for research data, including large and complex data types

- gold Open Access which fosters wider collaboration and increased citations

- maximum visibility for your research: over $100 \mathrm{M}$ website views per year

At BMC, research is always in progress.

Learn more biomedcentral.com/submissions 